\title{
APPLICATION OF THE LAW OF CHEMICAL EQUILIBRIUM (LAW OF MASS ACTION) TO BIOLOGICAL PROBLEMS
}

\author{
FRANKLIN C. MCLEAN \\ Department of Physiology, University of Chicago, Chicago, Illinois
}

The concept of balanced chemical reactions, introduced by Wenzel in $1777^{1}$ and made more exact by Berthollet in 1801, was put into the quantitatively useful form of the law of mass action by Guldberg and Waage in 1867. In 1877 van't Hoff showed how this law could be derived from the principles of thermodynamics, without introducing the vague idea of chemical force, and in 1887 Arrhenius applied the same law to the dissociation of electrolytes in solution.

The earliest applications of the law of chemical equilibrium, which was originally derived from the law of mass action, to physiological problems were that of Hüfner (1890) to the dissociation of oxyhemoglobin, and that of L. J. Henderson (1908), characterized by Peters and Van Slyke (1931) as "the first unified explanation of the physiological and physicochemical mechanisms by which the body maintains its normal acid-base balance."

This review will attempt to set forth the concepts essential to a working knowledge of the law of chemical equilibrium, and to illustrate the adaptability of this law to specific problems, rather than to assemble the many important though unrelated contributions which have made use of it. The equally important applications of the law of mass action to the kinetics of chemical reactions will be considered only in so far as they have been applied to physiological problems studied also by the law of chemical equilibrium.

The LAW of Chemical EQUILIBRIUM ${ }^{2}$. The law of mass action, as stated by Guldberg and Waagc, is essentially that the rate at which a substance reacts is proportional to its "active mass," and that the velocity of a chemical reaction is proportional, at any moment, to the

${ }^{1}$ For a full exposition of the history of chemical affinity and chemical equilibrium see M. M. Pattison Muir (1909).

2 For an extended development of the law of chemical equilibrium in homogeneous systems see Edgar (1931). For a simplified derivation from kinetics see Hogness and Johnson (1937) or Stieglitz (1911). 
product of the active masses of the substances reacting, and to a constant characteristic of the particular reaction (and of the temperature). Guldberg and Waage also pointed out clearly the general reversibility of chemical reactions, and derived from their consideration of the kinetics of such reactions the law of chemical equilibrium.

The more generally useful, and in some instances indispensable, derivation of the law of chemical equilibrium is that from the principles of thermodynamics, first applied to this law by van't Hoff. The derivation from the principles of kinetics, as applied by Guldberg and Waage, subsequently modified by the introduction of the activity concept, is adequate for the interpretation of the relationships of concentrations of reacting substances at equilibrium, and does not require familiarity with thermodynamics. In this review the effort is made to present the subject, wherever possible, without the introduction of thermodynamics, reserving the latter for those special uses of the law of chemical equilibrium which require its application.

The activity concept. In either case, use of the activity concept, although not always attainable in actual practice, is essential to an adequate statement of the law of chemical equilibrium and to definition of the limitations put upon this law when practical considerations prevent its full application. The term "active mass" as used by Guldberg and Waage had an indefinite meaning, ${ }^{3}$ but they pointed out that "molecular concentration" apparently could be substituted for it. The modern substitution of thermodynamically defined "activity" for the vague "active mass" makes possible a theoretically comprehensive and what Edgar (1931) calls a universally valid statement of the law of chemical equilibrium.

A full discussion of the concept of activity would be beyond the scope of this review. If it is desired to find an equivalent for the term, it may be thought of as the "apparent concentration" or "effective concentration," although these terms add nothing to the "active mass" of Guldberg and Waage. The activity of a "perfect gas" is equal to its pressure, and for any actual gas the activity approaches the pressure as the gas becomes dilute. In the case of aqueous solutions the activity of a solute approaches its molality as the solution becomes dilute. The activity of a solute is in part dependent upon properties of the solute

3 Guldberg and Waage defined the "active mass" of a substance as the quantity of it within "the sphere of attraction" or "the sphere of action." As they could not determine the absolute sizes of such spheres of action, they chose an arbitrary volume. 
itself and of the solvent, and in part upon the concentration of the solute itself and of other solutes. This effect of the concentration of a solution upon the activities of its solutes has been found in the case of electrolytes to depcnd more particularly upon the total "ionic strength" (Lewis and Randall, 1923) which is a function of the concentration and of the valences of ions in the solution.

The relationship between the molal concentration of a solute, under any particular conditions, and its activity is expressed by a factor known as the activity coefficient. The theory of Debye and Hückel ${ }^{4}$ attempts to account for the effects of various properties of solutes and solvents upon the activity coefficient, and for the empirical observation that the logarithm of the activity coefficient has a linear relationship to the square root of the ionic strength.

Dissociation of electrolytes. The concept of activity, arising in part out of efforts to explain the behavior of electrolytes in solution, has greatly modified the theory of their dissociation, to which the law of chemical equilibrium was first applied by Arrhenius. There is now almost universal acceptance of the belief that the so-called strong electrolytes are completely ionized in aqueous solution, the effect of increasing concentration upon conductivity and other properties of such solutions now being attributed to changes in the activities of the ions. Obviously, then, the law of chemical equilibrium can not be used as a measure of the degree of dissociation of strong electrolytes. On the other hand, the weak electrolytes, such as the weak acids and weak bases, are regarded as only partially ionized and the law of chemical equilibrium is applicable to their dissociation. There appear to be certain exceptions, some of them of biological interest, to the general rule that salts are strong electrolytes. Calcium and magnesium form salts with many weak acids, including proteins, whose behavior in solution is better explained by the assumption of partial dissociation than by application of the activity concept alone.

The law of chemical equilibrium from the standpoint of kinetics. As stated by Guldberg and Waage, but modified by introduction of the activity concept, the velocity of the reaction

$$
\mathrm{A}+\mathrm{B} \rightarrow \mathrm{C}+\mathrm{D}
$$

may be expressed by the equation

$$
v_{1}=k_{1} \times a_{A} \times a_{B}
$$

4 For full treatment of the Debye-Hückel theory see Taylor (1931). 
in which $v_{1}$ is the velocity of the reaction, $k_{1}$ is the velocity proportionality constant characteristic of this reaction, and $a_{A}$ and $a_{B}$ are the activities of $\mathrm{A}$ and $\mathrm{B}$.

For the reverse reaction

$$
\begin{aligned}
& \mathrm{A}+\mathrm{B} \leftarrow \mathrm{C}+\mathrm{D} \\
& v_{2}=k_{2} \times \mathrm{a}_{\mathrm{C}} \times \mathrm{a}_{\mathrm{D}}
\end{aligned}
$$

and for the reversible reaction

$$
\mathrm{A}+\mathrm{B} \rightleftharpoons \mathrm{C}+\mathrm{D}
$$

equilibrium, being by definition the condition at which the velocities of the two opposing reactions are equal, is defined by the equation

$$
\frac{a_{C} \times a_{D}}{a_{A} \times a_{B}}=\frac{k_{1}}{k_{2}}=K \quad \text { (equilibrium constant) }
$$

When one component appears more than once in a reaction, as

$$
\begin{aligned}
& \mathrm{A}+2 \mathrm{~B} \rightarrow \mathrm{C}+\mathrm{D} \\
& v_{1}=k_{1} \times \mathrm{a}_{\mathrm{A}} \times \mathrm{a}_{\mathrm{B}}^{2}
\end{aligned}
$$

and for equilibrium

$$
\frac{a_{C} \times a_{D}}{a_{A} \times a_{B}^{2}}=\frac{k_{1}}{k_{2}}=K
$$

which may be expanded, for the general case

$$
\mathrm{aA}+\mathrm{bB}+\cdots \cdots \mathrm{cC}+\mathrm{dD}+\cdots
$$

to

$$
\frac{a_{c}^{c} \times a_{D}^{d} \times \cdots}{a_{A}^{a} \times a_{B}^{b} \times \cdots}=K
$$

which is the universally valid statement of the law of chemical equilibrium.

In the case of equilibria of biological interest, equation 11 is rarely applicable for the reason that the activities of the various components can not be arrived at, the chief obstacles being uncertainty concerning both the activities of proteins and other complex substances in biological fluids, and the effects of these substances upon the activities of other 
solutes. Consequently it is usually necessary to make the simplifying assumption, as did Guldberg and Waage, that activities are proportional to molality and write equation 11 as

$$
\frac{[\mathrm{C}]^{\mathrm{c}} \times[\mathrm{D}]^{\mathrm{d}} \times \cdots}{[\mathrm{A}]^{\mathrm{a}} \times[\mathrm{B}]^{\mathrm{b}} \times \cdots}=K^{\prime}
$$

in which the brackets [] represent concentrations in terms of moles per kilogram of water and $K^{\prime}$ represents an apparent equilibrium constant.

Equation 12 may be transformed to the universally valid equation 11 by the introduction of factors which represent activity coefficients, thus

$$
a_{A}=f[A]
$$

The use of equation 12 , by omitting activity coefficients of the various components, implies the assumption that these coefficients remain constant. This condition is approximated in the case of dilute solutions of weak electrolytes, at constant ionic strength, which makes the use of equation 12 valid for most purposes under these limiting conditions. These limitations, to which further reference will be made, must of course be kept in mind whenever the attempt to use equation 12 is made.

The law of chemical equilibrium from the standpoint of thermodynamics. ${ }^{5}$ The general criterion of equilibrium is that the free energy of the system, or that part of the energy which may be made to do useful work, remains unchanged. Thus, for equilibrium

$$
\Delta F=0
$$

If we again consider the reaction

$$
\mathrm{aA}+\mathrm{bB} \rightleftharpoons \mathrm{cC}+\mathrm{dD}
$$

as applied to a system of perfect gases, we may imagine two different equilibrium systems $I$ and II, at pressures $P_{1}$ and $P_{2}$, with volumes so large that removal of small quantities of the reacting components does not alter the composition of the systems appreciably. From system I we remove a mols of $A$ and $b$ mols of $B$, at the partial pressures $P_{1_{A}}$ and $\mathrm{P}_{1_{\mathrm{B}}}$. For this step $\Delta F=0$, since the condition of equilibrium is not measurably disturbed. If the pressures of the gases withdrawn are

${ }^{5}$ The derivations which follow are given in greater detail by Edgar (1931). 
changed to $\mathrm{P}_{2_{A}}$ and $\mathrm{P}_{2_{B}}$, at which they exist in system $\mathrm{II}$, the free energy change, from the gas laws, is

$$
\Delta F_{1}=a R T \ln \frac{\mathrm{P}_{2_{\mathrm{A}}}}{\mathrm{P}_{1_{\mathrm{A}}}}+\mathrm{b} R T \ln \frac{\mathrm{P}_{2_{\mathrm{B}}}}{\mathrm{P}_{1_{\mathrm{B}}}}
$$

in which $R$ is the gas constant, $T$ the absolute temperature and ln the natural logarithm.

We may now introduce the gases into system II, and since this does not measurably disturb the equilibrium, again $\Delta F=0$ for this step.

If the process is simultaneously carried out in the reverse direction

$$
\Delta F_{2}=c R T \ln \frac{\mathrm{P}_{1_{\mathrm{C}}}}{\mathrm{P}_{{ }_{\mathrm{C}}}}+\mathrm{d} R T \ln \frac{\mathrm{P}_{1_{\mathrm{D}}}}{\mathrm{P}_{{ }^{\mathrm{D}}}}
$$

and at the end the composition of each system is what it was at the beginning, therefore

$$
\Delta F=\Delta F_{1}+\Delta F_{2}=0
$$

and from equations 15 and 16 , by rearrangement

$$
R T \ln \frac{\mathrm{P}_{2_{\mathrm{C}}}^{\mathrm{c}} \times \mathrm{P}_{{ }_{2} \mathrm{D}}^{\mathrm{d}}}{\mathrm{P}_{2_{\mathrm{A}}}^{\mathrm{a}} \times \mathrm{P}_{{ }_{\mathrm{B}}}^{\mathrm{b}}}=R T \ln \frac{\mathrm{P}_{1_{\mathrm{C}}}^{\mathrm{c}} \times \mathrm{P}_{1_{\mathrm{D}}}^{\mathrm{d}}}{\mathrm{P}_{1_{\mathrm{A}}}^{\mathrm{a}} \times \mathrm{P}_{1_{\mathrm{B}}}^{\mathrm{b}}}
$$

and

$$
\frac{\mathrm{P}_{{ }_{\mathrm{C}}}^{\mathrm{c}} \times \mathrm{P}_{{ }_{2} \mathrm{D}}^{\mathrm{d}}}{\mathrm{P}_{{ }_{\mathrm{A}}}^{\mathrm{a}} \times \mathrm{P}_{{ }_{\mathrm{B}}}^{\mathrm{b}}}=\frac{\mathrm{P}_{1_{\mathrm{C}}}^{\mathrm{c}} \times \mathrm{P}_{1_{\mathrm{D}}}^{\mathrm{d}}}{\mathrm{P}_{1_{\mathrm{A}}}^{\mathrm{a}} \times \mathrm{P}_{1_{\mathrm{B}}}^{\mathrm{b}}}
$$

or since these were any two sets of equilibrium pressures

$$
\frac{\mathrm{P}_{\mathrm{C}}^{\mathrm{c}} \times \mathrm{P}_{\mathrm{D}}^{\mathrm{d}}}{\mathrm{P}_{\mathrm{A}}^{\mathrm{a}} \times \mathrm{P}_{\mathrm{B}}^{\mathrm{b}}}=K
$$

which is identical, for a system of perfect gases, with equation 11, and which may equally well be derived for substances in solution, in the form of equation 11 .

By a similar process, and considering again the reaction

$$
\mathrm{aA}+\mathrm{bB} \rightleftharpoons \mathrm{cC}+\mathrm{dD}
$$

for a system of perfect gases the following expression may be derived for the free energy change for the reaction, letting $\mathrm{P}_{\mathrm{A}^{\prime}}$ and $\mathrm{P}_{\mathrm{B}^{\prime}}$ be the initial partial pressures of $A$ and $B, P_{C^{\prime}}$ and $P_{D^{\prime}}$ the final partial pressures of $C$ and $D$, and $P_{A}, P_{B}, P_{C}$ and $P_{D}$ the partial pressures of the four gases at equilibrium. 


$$
\Delta F=R T \ln \frac{\mathrm{P}_{\mathrm{C}^{\prime}}^{\mathrm{c}} \times \mathrm{P}_{\mathrm{D}^{\prime}}^{\mathrm{d}}}{\mathrm{P}_{\mathrm{A}^{\prime}}^{\mathrm{a}} \times \mathrm{P}_{\mathrm{B}^{\prime}}^{\mathrm{d}}}-R T \ln \frac{\mathrm{P}_{\mathrm{C}}^{\mathrm{c}} \times \mathrm{P}_{\mathrm{D}}^{\mathrm{d}}}{\mathrm{P}_{\mathrm{A}}^{\mathrm{a}} \times \mathrm{P}_{\mathrm{B}}^{\mathrm{b}}}
$$

and by substitution of equation 20

$$
\Delta F=R T \ln \frac{\mathrm{P}_{\mathrm{C}^{\prime}}^{\mathrm{c}} \times \mathrm{P}_{\mathrm{D}^{\prime}}^{\mathrm{d}}}{\mathrm{P}_{\mathrm{A}^{\prime}}^{\mathrm{a}} \times \mathrm{P}_{\mathrm{B}^{\prime}}^{\mathrm{b}}}-R T \ln K
$$

The free energy increase of "the reaction is thus seen to be determined, at constant temperature, by the equilibrium constant and by the initial and final partial pressures of the reacting species. If $\mathrm{P}_{\mathrm{A}^{\prime}}, \mathrm{P}_{\mathrm{B}^{\prime}}, \mathrm{P}_{\mathrm{C}^{\prime}}$ and $\mathrm{P}_{\mathrm{D}^{\prime}}$ are all equal to unity, equation 22 becomes

$$
\Delta F=-R T \ln K
$$

This derivation has the advantage that it relates the equilibrium constant to the free energy change of the reaction, a quantity which is of especial interest in the study of the energy metabolism of biological organisms. The free energy change may also be calculated from thermochemical data, and in the case of electromotively active systems from electrode potentials. Consequently data obtained in a variety of ways may be expressed in terms of the equilibrium constant, of the change in free energy, or of electrode potentials, according to the requirements of the particular problem under investigation.

Dissociation of oxyнemoglobin. The first attempt at application of the law of chemical equilibrium to a biochemical problem appears to have been that of Hüfner (1890) to the dissociation of oxyhemoglobin. It is of interest that this first and apparently obvious application has not yet been completely successful in interpreting the equilibrium between oxygen and hemoglobin.

Making the assumption that one molecule of oxygen combines with one molecule of hemoglobin, and hence from the equation

$$
\mathrm{HbO}_{2} \rightleftharpoons \mathrm{Hb}+\mathrm{O}_{2}
$$

Hüfner wrote the simple mass-law equation

$$
\frac{[\mathrm{Hb}] \times\left[\mathrm{O}_{2}\right]}{\left[\mathrm{HbO}_{2}\right]}=K^{6}
$$

6 Throughout this review we have followed the convention of placing the dissociating substance on the left hand side of the stoichiometric equations and in the denominator of mass-law equations. For this reason mass-law equations, as compared with those originally published, will at times be found inverted. 
This equation was found by Barcroft (1914) to agree fairly well with experimental data in the case of dialyzed (salt-free) hemoglobin. It was found very early, however, that equation 25 was not applicable to the dissociation of oxyhemoglobin in blood, or in solutions containing salts. The earlier history of this subject is extensively reviewed by Barcroft.

Aggregation hypothesis. Hill (1910), in an attempt to explain the behavior of hemoglobin in the presence of salts, and still assuming that one molecule of $\mathrm{Hb}$ in distilled water combined with one molecule of $\mathrm{O}_{2}$, amplified equation 24 with the object of ascertaining the shapes of the dissociation curves which would be obtained on the assumption that the molecules of hemoglobin fall into aggregates as the result of the addition of salts. He reasoned that if on the average there were $n$ molecules of $\mathrm{Hb}$ in each aggregate, and if one molecule of $\mathrm{Hb}$ combined with one molecule of $\mathrm{O}_{2}$, equation 24 would become

$$
\mathrm{Hb}_{n}\left(\mathrm{O}_{2}\right)_{n} \rightleftharpoons \mathrm{Hb}_{n}+n \mathrm{O}_{2}
$$

and making the assumption that each aggregate of $\mathrm{Hb}_{n}$ behaved from the standpoint of mass action as though it were one molecule, equation 25 would become

$$
\frac{\left[\mathrm{Hb}_{n}\right] \times\left[\mathrm{O}_{2}\right]^{n}}{\left[\mathrm{Hb}_{n}\left(\mathrm{O}_{2}\right)_{n}\right]}=K
$$

or more simply

$$
\frac{[\mathrm{Hb}] \times\left[\mathrm{O}_{2}\right]^{n}}{\left[\mathrm{HbO}_{2}\right]}=K \quad \text { (Hill-Barcroft equation) }
$$

The value for $n$ in this equation was found to be nearly constant at 2.5 in the presence of salts, the value for $K$ varying with different species and to some extent with different individuals, and as later found (Henderson, 1920) with the $\mathrm{CO}_{2}$ tension, or, more properly, with the $\mathrm{pH}$.

The finding of a value of 2.5 for $n$ in equation 28 was interpreted as supporting the aggregation hypothesis, which received further support from the measurement of the heat of reaction of hemoglobin and oxygen by Brown and Hill (1923). Later work, however, by other methods, led to general acceptance of a molecular weight for hemoglobin corresponding to a combination of 4 molecules of $\mathrm{O}_{2}$ with each molecule of hemoglobin. Simple application of the law of chemical equilibrium to the larger molecular weight would involve rejection of the aggregation hypothesis and the writing of equation 24 as 


$$
\mathrm{HB}\left(\mathrm{O}_{2}\right)_{4} \rightleftharpoons \mathrm{HB}+4 \mathrm{O}_{2}{ }^{7}
$$

from which equation 25 would become

$$
\frac{[\mathrm{HB}]}{\left[\mathrm{HB}\left(\mathrm{O}_{2}\right)_{4}\right]}=K
$$

from which it is seen that the value of $n$ in equations 27 and 28 should be 4 instead of 2.5 for this simple treatment to be applicable, and that equation 30 should also hold for solutions of dialyzed hemoglobin.

Intermediate compound formation. Adair (1925) and Ferry and Green (1929) attempted to explain these discrepancies by a theory of intermediate compound formation, a possibility also considered by Barcroft. This theory, which is consistent with the experimental data, but for which no satisfactory proof is available, owing to the number of constants involved, assumes that $\mathrm{HB}$, in the presence of $\mathrm{O}_{2}$, forms the series $\mathrm{HBO}_{2}, \mathrm{HB}\left(\mathrm{O}_{2}\right)_{2}, \mathrm{HB}\left(\mathrm{O}_{2}\right)_{3}, \mathrm{HB}\left(\mathrm{O}_{2}\right)_{4}$, each with a different dissociation constant. Adair also attempted to reconcile the apparent difference in behavior of hemoglobin in the presence and in the absence of salts by introducing corrections for the change in acid strength of hemoglobin on oxygenation, and showed also that the thermal data of Brown and Hill are consistent with the hypothesis of intermediate compound formation.

Sidwell, Munch, Barron, and Hogness (1938) have recently reviewed the sources of difficulty in analyzing the equilibrium between hemoglobin and oxygen, and have called attention to the necessity of re-study of the effects of electrolytes upon this equilibrium. They present data concerning the inhibition of oxygenation of dialyzed hemoglobin on addition of varying amounts of different salts, and after consideration of ionic strength effects conclude that in some cases the inhibiting effect is very probably due to the direct combination of anions with hemoglobin, a possibility also postulated by Roughton (1935). They also point out that bicarbonate has the greatest effect of the salts studied, and that a direct combination of $\mathrm{HCO}_{3}$ - ions with hemoglobin may be of physiological importance by influencing the uptake and output of oxygen by the blood. Their experiments were performed at the iso-

${ }^{7}$ Even though it is now believed that one molecule of hemoglobin combines with 4 molecules of $\mathrm{O}_{2}$ the symbol $\mathrm{HbO}_{2}$ persists in the literature. We shall continue to employ $\mathrm{Hb}$ to indicate the $\mathrm{O}_{2}$ combining groups of hemoglobin, each corresponding to one atom of iron, and $\mathrm{HB}$ to indicate the molecule of hemoglobin. By this notation $\mathrm{HB}=\mathrm{Hb}_{4}$. 
electric point of hemoglobin, thus minimizing the influence of carbamino compounds with $\mathrm{CO}_{2}$ upon the oxygenation of hemoglobin (Stadie and O'Brien, 1937).

The history of the problem of the dissociation of oxyhemoglobin is in part the history of the discovery of additional properties of hemoglobin. To Hüfner's first simple conception of the equilibrium between hemoglobin and oxygen there have had to be added the influences of electrolytes, of the variable acid strength of hemoglobin with oxygenation, and of the carbamino compounds with $\mathrm{CO}_{2}$. Resolution of the difficulties in applying the law of chemical equilibrium to this problem will perhaps serve as an indication that the major properties of hemoglobin have been recognized.

The ACID-BASE BaLANCE. The law of chemical equilibrium, with special reference to the dissociation of carbonic acid, was first applied to the study of the acid-base balance by L. J. Henderson (1908), and modern treatment of the subject is a direct derivation of this application.

Carbonic acid dissociates in two steps, to which the following masslaw equations apply

$$
\begin{aligned}
& \frac{\mathrm{a}_{\mathrm{H}^{+}} \times \mathrm{a}_{\mathrm{HCO}_{3}^{-}}}{\mathrm{a}_{2} \mathrm{CO}_{3}}=K_{1 \mathrm{H}_{2} \mathrm{CO}_{3}} \\
& \frac{\mathrm{a}_{\mathrm{H}^{+}} \times \mathrm{a}_{\mathrm{CO}_{3}^{-}}}{a_{\mathrm{HCO}_{3}^{-}}}=K_{2 \mathrm{H}_{2} \mathrm{CO}_{3}}
\end{aligned}
$$

The second dissociation does not yield quantitatively significant amounts of $\mathrm{CO}_{3}^{-}$below $\mathrm{pH} 7.8$, and has but little biological application.

Henderson pointed out that in a mixture of bicarbonate and dissolved $\mathrm{CO}_{2}$, when the concentration of $\mathrm{BHCO}_{3}$ is of the order of magnitude of that present in plasma and exceeds 10 per cent of that of $\mathrm{CO}_{2}$, the $\mathrm{HCO}_{3}^{-}$ions derived from $\mathrm{H}_{2} \mathrm{CO}_{3}$ are negligible in comparison with those from $\mathrm{BHCO}_{3}$. Moreover, in accordance with the assumption, current at the time, that $\mathrm{BHCO}_{3}$ was only partially dissociated, he introduced a factor to indicate the degree of dissociation, and wrote

$$
\frac{\left[\mathrm{H}^{+}\right] \times \mathrm{f}\left[\mathrm{BHCO}_{3}\right]}{\left[\mathrm{H}_{2} \mathrm{CO}_{3}\right]}=K
$$

or letting $K^{\prime}=K / \mathfrak{f}$

$$
\frac{\left[\mathrm{H}^{+}\right] \times\left[\mathrm{BHCO}_{3}\right]}{\left[\mathrm{H}_{2} \mathrm{CO}_{3}\right]}=K^{\prime} \quad \text { (apparent dissociation constant) }
$$


For convenience Hasselbalch (1916-17) put this equation into the logarithmic form

$$
\mathrm{pH}=\mathrm{p} K^{\prime}+\log \frac{\left[\mathrm{BHCO}_{3}\right]}{\left[\mathrm{H}_{2} \mathrm{CO}_{3}\right]}
$$

or the classical Henderson-Hasselbalch equation, in which the symbol $\mathrm{p}=-\log$.

Ccrtain limitations are imposed upon the applications of equation 35, chiefly by the limitations of the analytical data available. In general, the quantities which may be measured or estimated being $\mathrm{pH}$, total $\mathrm{CO}_{2}$, and dissolved $\mathrm{CO}_{2}$ (which includes $\mathrm{H}_{2} \mathrm{CO}_{3}$ ) this equation, in practice, assumes the form

$$
\mathrm{pH}=\mathrm{p} K_{\mathrm{CO}_{2}}^{\prime}+\log \frac{\left[\text { total } \mathrm{CO}_{2}-\text { dissolved } \mathrm{CO}_{2}\right]}{\left[\text { dissolved } \mathrm{CO}_{2}\right]}
$$

which satisfactorily represents the conditions at constant ionic strength in systems containing $\mathrm{CO}_{2}$ only as $\mathrm{HCO}_{3}^{-}$, dissolved $\mathrm{CO}_{2}$, and $\mathrm{H}_{2} \mathrm{CO}_{3}$. There are many observations to the effect that this equation may be applied, without further correction, to serum or plasma in equilibrium with $\mathrm{CO}_{2}$. The applications of this equation are extensively reviewed by Peters and Van Slyke, and the newer literature by Sendroy (1938).

Hudration of $\mathrm{CO}_{2}$. When $\mathrm{CO}_{2}$ is dissolved in water the reaction

$$
\mathrm{CO}_{2}+\mathrm{H}_{2} \mathrm{O} \rightleftharpoons \mathrm{H}_{2} \mathrm{CO}_{3}
$$

occurs. The earliest determinations of the dissociation constant of carbonic acid (Walker and Cormack) implied the assumption that this reaction proceeds to completion, by treating all dissolved $\mathrm{CO}_{2}$ as $\mathrm{H}_{2} \mathrm{CO}_{3}$. By 1914 Thiel and Strohecker had shown that only a small fraction, not yet accurately determined but now estimated at 1/400 - 1/1000, of dissolved $\mathrm{CO}_{2}$ is hydrated to $\mathrm{H}_{2} \mathrm{CO}_{3}$ at equilibrium. As pointed out by Van Slyke (1921) the mass law equation

$$
\frac{\left[\mathrm{CO}_{2}\right] \times\left[\mathrm{H}_{2} \mathrm{O}\right]}{\left[\mathrm{H}_{2} \mathrm{CO}_{3}\right]}=K
$$

applies to reaction 37 , and since $\left[\mathrm{H}_{2} \mathrm{O}\right]$ is constant the ratio $\left[\mathrm{CO}_{2}\right] /$ $\left[\mathrm{H}_{2} \mathrm{CO}_{3}\right]$ is constant at equilibrium. If the proportion of $\mathrm{CO}_{2}$ hydrated to $\mathrm{H}_{2} \mathrm{CO}_{3}$ at equilibrium is designated by a factor then equation 34 becomes

$$
\frac{\left[\mathrm{H}^{+}\right] \times\left[\mathrm{BHCO}_{3}\right]}{\mathrm{f}\left[\mathrm{CO}_{2}\right]}=K^{\prime}
$$


and

$$
\frac{\left[\mathrm{H}^{+}\right] \times\left[\mathrm{BHCO}_{3}\right]}{\left[\mathrm{CO}_{2}\right]}=\mathrm{f} K^{\prime}
$$

Consequently the effect of assuming all dissolved $\mathrm{CO}_{2}$ to be in the form of $\mathrm{H}_{2} \mathrm{CO}_{3}$ is to modify the true value of $K^{\prime}$ by an unknown factor $\mathrm{f}$. Thus the convention, still in use, of representing all dissolved $\mathrm{CO}_{2}$ as $\mathrm{H}_{2} \mathrm{CO}_{3}$ in the Henderson-Hasselbalch equation 35 introduces no error of calculation provided that the equation is applied only to equilibrium conditions.

Within the past ten years a new chapter has been added to the study of the acid-base balance in its relationship to the transport of $\mathrm{CO}_{2}$ by the blood. The relationships which have been discussed above had up until 1928 been studied by methods which permitted equilibrium to be attained, without, as it now appears, sufficient regard for the shortness of time that the blood spends in the capillaries of the lungs and other tissues. Largely owing to the pioneer work of Henriques (1928) attention has been directed to the kinetics of the carbon dioxide processes in the blood. The results of this work have been extensively reviewed by Roughton and will be discussed here only in so far as they concern applications of the law of chemical equilibrium to the problem.

By reference to equations 2 and 4 above, expressions for the velocity of reaction 37 may be obtained, as follows. For the reaction $\mathrm{H}_{2} \mathrm{CO}_{3} \rightarrow$ $\mathrm{CO}_{2}+\mathrm{H}_{2} \mathrm{O}$ the reaction velocity

$$
d\left[\mathrm{H}_{2} \mathrm{CO}_{3}\right] / d t=-k_{\mathrm{H}_{2} \mathrm{CO}_{3}}\left[\mathrm{H}_{2} \mathrm{CO}_{3}\right]
$$

in which $k_{\mathrm{H}_{2} \mathrm{CO}_{3}}$ is the dehydration velocity constant of $\mathrm{H}_{2} \mathrm{CO}_{3}$, and for the reaction $\mathrm{CO}_{2}+\mathrm{H}_{2} \mathrm{O} \rightarrow \mathrm{H}_{2} \mathrm{CO}_{3}$

$$
d\left[\mathrm{CO}_{2}\right] / d t=-k_{\mathrm{CO}_{2}}\left[\mathrm{CO}_{2}\right]
$$

in which $k_{\mathrm{CO}_{2}}$ is the hydration velocity constant of $\mathrm{CO}_{2}$.

For the reversible reaction 37 there may be written

$$
d\left[\mathrm{CO}_{2}\right] / d t=-k_{\mathrm{CO}_{2}}\left[\mathrm{CO}_{2}\right]+k_{\mathrm{H}_{2} \mathrm{CO}_{3}}\left[\mathrm{H}_{2} \mathrm{CO}_{3}\right]
$$

which, according to Roughton is well supported by experimental evidence. Study of the kinetics of this reaction by this derivation of the law of mass action led to the discovery of the enzyme, carbonic anhydrase, which greatly accelerates reaction 37 in both directions.

The establishment of a definite time factor in the hydration of $\mathrm{CO}_{2}$ to $\mathrm{H}_{2} \mathrm{CO}_{3}$, and in the reverse process of dehydration of $\mathrm{H}_{2} \mathrm{CO}_{3}$ means 
that the assumption of a constant $\left[\mathrm{CO}_{2}\right] /\left[\mathrm{H}_{2} \mathrm{CO}_{3}\right]$ ratio, under all conditions, is no longer tenable. While, as previously stated, this involves no error of calculation in systems at equilibrium, the assumption of a constant ratio during the uptake of $\mathrm{CO}_{2}$ in the tissues and its discharge in the lungs does introduce a possible error of thought with relation to the processes involved. For this reason we strongly support the plea of Stadie and O'Brien (1937) for the adoption of a system of notation which clearly indicates the processes and assumptions inherent in the application of the law of chemical equilibrium to the conditions in a $\mathrm{BHCO}_{3} / \mathrm{CO}_{2}$ system.

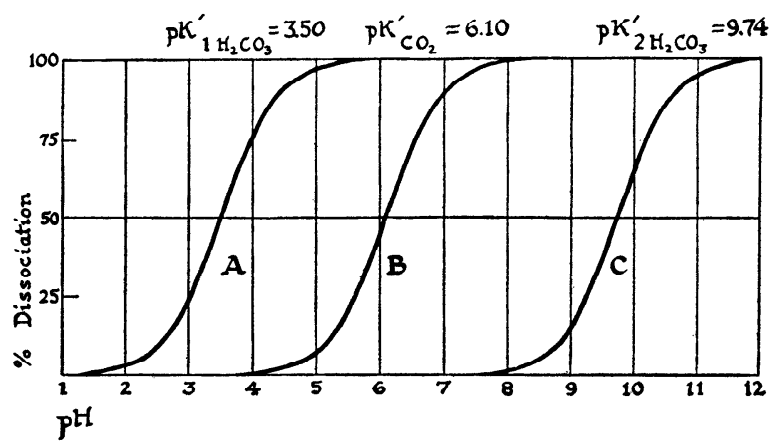

Fig. 1. "Dissociation curves" of carbonic acid. \% Dissociation represents in Curve $\mathrm{A}-\%$ of $\mathrm{HCO}_{3}^{-}+\mathrm{H}_{2} \mathrm{CO}_{3}$ as $\mathrm{HCO}_{3}{ }^{-}$Curve $\mathrm{B}-\%$ of $\mathrm{HCO}_{3}^{-}+\mathrm{CO}_{2}+$ $\mathrm{H}_{2} \mathrm{CO}_{3}$ as $\mathrm{HCO}_{3}^{-}$Curve $\mathrm{C}-\%$ of $\mathrm{CO}_{3}{ }^{-}+\mathrm{HCO}_{3}^{-}$as $\mathrm{CO}_{3}^{-}$.

Stadie and O'Brien propose two equations for such a system, as follows:

$$
\begin{gathered}
\mathrm{pH}=\mathrm{p} K_{\mathrm{CO}_{2}}^{\prime}+\log \frac{\left[\mathrm{HCO}_{3}^{-}\right]}{\left[\mathrm{CO}_{2}\right]} \quad\left(\mathrm{pK}_{\mathrm{CO}_{2}}^{\prime}=6.10\right) \\
\mathrm{pH}=\mathrm{p} K_{\mathrm{H}_{2} \mathrm{CO}_{3}}^{\prime}+\log \frac{\left[\mathrm{HCO}_{3}^{-}\right]}{\left[\mathrm{H}_{2} \mathrm{CO}_{3}\right]}\left(\mathrm{p}_{1 \mathrm{H}_{2} \mathrm{CO}_{3}}^{\prime}=3.5 \text { approximately }\right)
\end{gathered}
$$

The two equations give identical results when dissolved $\mathrm{CO}_{2}$ and $\mathrm{H}_{2} \mathrm{CO}_{3}$ are at equilibrium, but only equation 45 expresses the condition of ionic equilibrium with non-equilibrium between $\mathrm{CO}_{2}$ and $\mathrm{H}_{2} \mathrm{CO}_{3}$. These two equations are shown graphically in figure 1. The same figure includes a graphic representation of the equation

$$
\mathrm{pH}=\mathrm{p} K_{2 \mathrm{H}_{2} \mathrm{CO}_{3}}^{\prime}+\log \frac{\left[\mathrm{CO}_{3}^{-}\right]}{\left[\mathrm{HCO}_{3}^{-}\right]} \quad\left(\mathrm{p}_{2}^{\prime}{ }_{\mathrm{H}_{2} \mathrm{CO}_{3}}^{\prime}=9.74\right)
$$

derived from equation 32 . 
Since curve $\mathrm{B}$ depends upon equilibrium between $\mathrm{CO}_{2}$ and $\mathrm{H}_{2} \mathrm{CO}_{3}$, it has no quantitative meaning for the condition of non-equilibrium, while curves $\mathrm{A}$ and $\mathrm{C}$ depend only upon ionic equilibrium, assumed to be instantaneous. In considering conditions of non-equilibrium, curve B is of value not as representing the conditions at any moment but as representing the limiting conditions toward which the system tends to move. The pathways followed are not along curve $\mathrm{B}$ but along curve $\mathrm{A}$, returning to curve $\mathrm{B}$ only at the instant equilibrium is attained.

For the contents of the red blood cells this limitation upon equation 44 probably introduces no serious error of thought. While hydration and dehydration of $\mathrm{CO}_{2}$ in the red cells, during $\mathrm{CO}_{2}$ uptake and discharge, occur only when $\mathrm{CO}_{2}$ and $\mathrm{H}_{2} \mathrm{CO}_{3}$ are not in equilibrium, hydration and dehydration are greatly accelerated by the presence of carbonic anhydrase, and are probably very nearly as rapid as the interionic reactions. In both the lungs and the tissues, however, $\mathrm{CO}_{2}$ must diffuse through the plasma with relatively little direct effect upon the $\mathrm{H}^{+}$ concentration of this fluid, owing to the absence of carbonic anhydrase. The physiological implications of this are more fully discussed by Roughton but it is apparent that equation 44 and curve $\mathrm{B}$ of figure 1 give a somewhat incorrect conception of the conditions in the plasma during the brief periods of passage through the capillaries of the tissues and lungs.

Ionic activity. It will be noted that in equations 44 and $45 \mathrm{BHCO}_{3}$ has been replaced by the $\mathrm{HCO}_{3}^{-}$of equation 31 . This is in accord with modern theory, which assumes complete dissociation of $\mathrm{BHCO}_{3}$ and replaces the concept of incomplete dissociation with that of activity.

In order to obtain equation 44 in the more generally applicable form of equation 31, Hastings and Sendroy (1925) made the assumption that the activity coefficient of dissolved $\mathrm{CO}_{2}$ is unity, and since $\mathrm{a}_{\mathrm{HCO}_{3}^{-}}=$ $\mathrm{f}\left[\mathrm{HCO}_{3}^{-}\right]$, wrote

$$
\mathrm{pa}_{\mathrm{H}^{+}}=\mathrm{p} K_{\mathrm{CO}_{2}}+\log \frac{\mathrm{f}\left[\mathrm{HCO}_{3}^{-}\right]}{\left[\mathrm{CO}_{2}\right]}
$$

from which

$$
\mathrm{pa}_{\mathrm{H}^{+}}=\mathrm{p} K_{\mathrm{CO}_{2}}+\log \mathrm{f}_{\mathrm{HCO}_{3}^{-}}+\log \frac{\left[\mathrm{HCO}_{3}^{-}\right]}{\left[\mathrm{CO}_{2}\right]}
$$

They found a value of 6.33 for $\mathrm{p} K_{\mathrm{CO}_{2}}$ at $38^{\circ} \mathrm{C}$., and in accord with the Debye-Hückel theory a value of $-0.5 \sqrt{\mu}$ for $\log \mathrm{f}_{\mathrm{HCO}_{3}^{-}}$. Consequently $\mathrm{p} K^{\prime} \mathrm{CO}_{2}$ of equation $44=6.33-0.5 \sqrt{\mu}$, which becomes 6.10 at the 
ionic strength of plasma. Use of the equation in this form is necessary when applied to solutions of ionic strength differing from that of plasma.

Buffer action. No review of the acid base balance would be complete without reference to the important concept of buffer action, which in theory and practice is a direct derivation of the law of chemical equilibrium as applied to the dissociation of weak acids and bases. Little can be added to the analysis of this subject in an important paper by Van Slyke (1922) except to point out the relationships of the buffer action of the system $\mathrm{HCO}_{3}^{-} / \mathrm{CO}_{2}$ to the considerations set forth in equations 44 and 45 above.

It is clear, from theoretical considerations alone, that such a system has in fact two buffer values. The first, defined by $\mathrm{p}_{1 \mathrm{H}_{2} \mathrm{CO}_{3}}^{\prime}$ of equation 45 , is the immediate buffer effect of the system $\mathrm{HCO}_{3}^{-} / \mathrm{H}_{2} \mathrm{CO}_{3}$. The second, defined by $\mathrm{p}^{\prime} \mathrm{CO}_{2}$ from equation 44 is the buffer effect of the system $\mathrm{HCO}_{3}^{-} / \mathrm{CO}_{2}$ at equilibrium, and is the buffer effect which has been chiefly studied. The consequences of this double effect, depending upon the time required for equilibrium between dissolved $\mathrm{CO}_{2}$ and $\mathrm{H}_{2} \mathrm{CO}_{3}$ to be attained have in part been discussed above. When a strong acid is added to the system $\mathrm{HCO}_{3}^{-} / \mathrm{CO}_{2}$ in the absence of carbonic anhydrase the immediate effect is a sharp increase in $\mathrm{H}^{+}$concentration to the $\mathrm{pH}$ as defined by equation 45 , followed by a much slower rise in $\mathrm{pH}$ to that defined by equation 44 . It was this phenomenon, first studied by colorimetric methods, which led Thiel and Strohecker to the conclusion that only a small fraction of dissolved $\mathrm{CO}_{2}$ is hydrated to $\mathrm{H}_{2} \mathrm{CO}_{3}$ at equilibrium, and Faurholt (1924) to a study of the kinetics of the hydration process.

The rôle of hemoglobin in the acid-base balance. In the development of the modern theory of the acid-base balance the view was generally held up to 1920 that hemoglobin played a purely passive part, limited to its buffer action as a protein. It had previously been suggested, from several sources, that oxyhemoglobin is a stronger acid than reduced hemoglobin, but the matter was first studied systematically by L. J. Henderson (1920), who applied the law of chemical equilibrium to the problem and was able to make tentative estimates of the acid dissociation constants of the two forms of hemoglobin and to point out the far reaching physiological consequences of this unique property. For a review of this important application of the law of chemical equilibrium, which has been abundantly confirmed and extended, reference is made to Henderson's monograph (1928).

A further major discovery concerning the part played by hemoglobin 
in the transport of $\mathrm{CO}_{2}$ in the blood arose out of difficulties in applying equation 36 to solutions containing hemoglobin. Van Slyke, Hastings, Murray and Sendroy (1925) found that the presence of hemoglobin affected the values found for $\mathrm{p} K_{\mathrm{CO}_{2}}^{\prime}$. Stadie and Hawes (1928) and Margaria and Green (1933) found further that the values for $\mathrm{p}_{\mathrm{CO}_{2}}^{\prime}$ depended upon the state of the hemoglobin with respect to oxygenation. Henriques, and Margaria and Green suggested that these deviations could be most simply explained by the assumption that part of the total $\mathrm{CO}_{2}$ was directly bound to hemoglobin as a carbamate. The history of the verification of this hypothesis, arising out of the application of the law of mass action, is extensively reviewed by Roughton. The carbamates represent a direct combination between amino acids or proteins and $\mathrm{CO}_{2}$, as follows

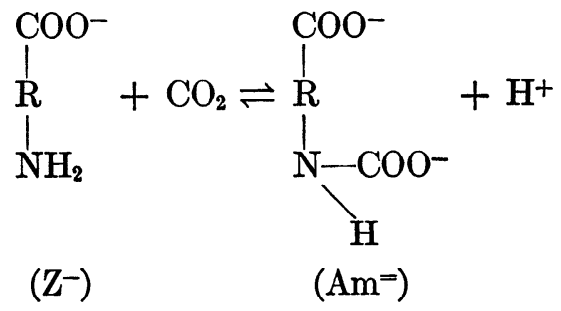

Stadie and O'Brien (1935-36) have applied the law of mass action to reaction 49 in the case of simple amino acids. When no $\mathrm{CO}_{2}$ is present as carbonate or bicarbonate they write

$$
\frac{\left[\mathrm{Am}^{=}\right] \times\left[\mathrm{H}^{+}\right]}{\left[\mathrm{Z}^{-}\right] \times\left[\mathrm{CO}_{2}\right]}=K_{\mathrm{Am}}
$$

and find that this equation satisfactorily represents the experimental data under a variety of conditions. For their treatment of the total equilibrium of amino acid and $\mathrm{CO}_{2}$, including both the carbamate and carbonate equilibria reference is made to their original paper.

Stadie and O'Brien (1937) have also applied the law of mass action to the carbamate equilibrium in the case of hemoglobin, and have accounted by this means for the distribution of $\mathrm{CO}_{2}$ in its different forms in the blood. Their fundamental equations, slightly revised in agreement with Stadie (personal communication) are, for the non-carbonate equilibrium

$$
\begin{gathered}
\mathrm{Hb}^{-}+\mathrm{CO}_{2} \rightleftharpoons \mathrm{HbAm}^{=}+\mathrm{H}^{+} \\
\frac{\left[\mathrm{HbAm}^{-}\right] \times\left[\mathrm{H}^{+}\right]}{\left[\mathrm{CO}_{2}\right] \times\left[\mathrm{Hb}^{-}\right]}=K
\end{gathered}
$$


from which, by combination with equation 44 , the total equilibrium which includes bicarbonate as well as carbamate may be formulated.

Graphic representation of the acid-base balance. The acid-base balance is in its simplest form characterized by three variables from equation 36 , viz., $\mathrm{pH}$, total $\mathrm{CO}_{2}$, and dissolved $\mathrm{CO}_{2}$ (which includes $\mathrm{H}_{2} \mathrm{CO}_{3}$ ). From total $\mathrm{CO}_{2}-$ dissolved $\mathrm{CO}_{2}=\mathrm{HCO}_{3}-$ a fourth variable is obtained. Visualization of the relationships between these variables is greatly

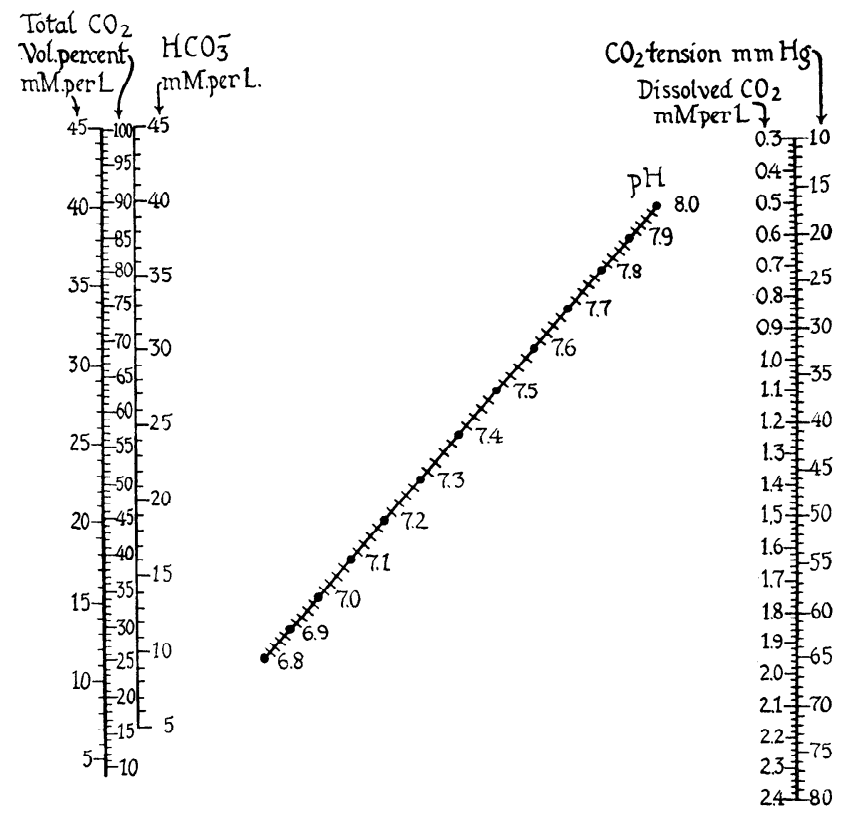

Fig. 2. Line chart for graphic calculation of serum or plasma values by the Henderson-Hasselbalch equation (equation 36 of text). A straight line through given points on any two scales cuts the other two scales at points indicating simultaneously occurring values.

facilitated by graphic analysis, of which Peters and Van Slyke give many examples. For use in calculation a previously unpublished line chart is here reproduced (fig. 2) which serves the same purposes as that published by Van Slyke and Sendroy (1928) but which has the advantage of theoretically exact scales for all of the variables. ${ }^{8}$ Sendroy, Seelig, and Van Slyke (1934) have also published a theoretically exact

${ }^{8}$ The construction of line charts is greatly aided by the methods employed by Allcock and Jones (1932), involving the use of determinants. 
line chart for calculation of any one of the three variables, total $\mathrm{CO}_{2}$, dissolved $\mathrm{CO}_{2}$, and $\mathrm{pH}$ from the other two in urine. By the use of appropriate values for the constants a similar chart could be constructed for the same three variables in plasma.

Equation 36 is peculiarly adapted to the use of triangular coördinates. Hastings and his co-workers (Hastings and Steinhaus, 1931; Shock and Hastings) have made use of this method of graphic analysis of the paths of displacement and of recovery of the acid-base balance. Sendroy (1938) gives other examples of recent applications of graphic calculation to this field.

The dissociation of calcium citrate. Sabbatani (1901), to explain the effect of citrate in preventing the coagulation of blood, arrived at the hypothesis that calcium forms a complex ion with citrate. Hastings, McLean, Eichelberger, Hall and DaCosta (1934) confirmed the evidence which had accumulated in support of this hypothesis, and arrived at dissociation constants for the citrates of calcium, magnesium and strontium.

The dissociation of the alkaline earth salts of citric acid is complicated by the fact that this acid, being trivalent, has three dissociation constants. Hastings et al. were able to make observations of $\mathrm{Ca}^{++}$concentrations by means of the frog heart method at $\mathrm{pH} 7.0$ or above, in a range in which citric acid may be regarded as completely dissociated. In this range they found evidence that calcium citrate dissociates in two stages. The primary dissociation

$$
\mathrm{Ca}_{3} \mathrm{Cit}_{2}=\mathrm{Ca}(\mathrm{CaCit})_{2} \rightleftharpoons \mathrm{Ca}^{++}+2 \mathrm{CaCit}^{-}
$$

appears to be that of a strong electrolyte, and may be regarded as complete.

The secondary dissociation,

$$
\mathrm{CaCit}^{-} \rightleftharpoons \mathrm{Ca}^{++}+\mathrm{Cit}^{\equiv}
$$

is that of a weak electrolyte, and Hastings et al. found it to be described by the mass law equation

$$
\frac{\left[\mathrm{Ca}^{++}\right] \times\left[\mathrm{Cit}^{\mathrm{s}}\right]}{[\mathrm{CaCit}]}=K_{\mathrm{CaCit}^{-}}=10^{-3.22},
$$

at $\mathrm{pH} 7.4,22^{\circ} \mathrm{C}$. and $\mu=0.155$ to 0.163 .

Hastings et al. made further use of the law of mass action in arriving at this constant by a wholly chemical method. For a difficultly soluble 
salt such as $\mathrm{CaCO}_{3}$ in solution in equilibrium with its solid phase, the mass law equation may be written

$$
\frac{\left[\mathrm{Ca}^{++}\right] \times\left[\mathrm{CO}_{3}^{-}\right]}{\left[\mathrm{CaCO}_{3}\right]}=K
$$

and since under these conditions $\left[\mathrm{CaCO}_{3}\right]$ in solution may be assumed to be constant

$$
\left[\mathrm{Ca}^{++}\right] \times\left[\mathrm{CO}_{3}=\right]=K_{\text {s.p. } \mathrm{CaCO}_{3}}
$$

which represents the familiar solubility product constant. ${ }^{9}$ By equilibrating citrate-containing solutions with solid $\mathrm{CaCO}_{3}$ at known $\mathrm{CO}_{2}$ tensions the $\mathrm{Ca}^{++}$concentration was calculated, and by this means a value of $10^{-3.31}$ for $K_{\mathrm{CaCit}}-$ was arrived at.

Muus and Lebel (1936) by calculation of $\mathrm{Ca}^{++}$concentrations from the solubility product constant of calcium iodate, by the method just described, found a value of $10^{-3.21}$ for $K_{\mathrm{CaCit}}$ - thus confirming the value found by the frog-heart method. These workers were also able to extend their observations to a lower $\mathrm{pH}$ range in which the dissociation

$$
\mathrm{HCit}^{=} \rightleftharpoons \mathrm{H}^{+}+\mathrm{Cit}^{=}
$$

is incomplete and may be represented by the mass law equation

$$
\frac{\left[\mathrm{H}^{+}\right] \times\left[\mathrm{Cit}^{=}\right]}{[\mathrm{HCit}=]}=K_{3 \mathrm{H}_{3} \mathrm{Cit}}
$$

In this range they postulated the reaction

$$
\mathrm{CaHCit} \rightleftharpoons \mathrm{Ca}^{++}+\mathrm{HCit}^{=}
$$

and found that

$$
\frac{\left[\mathrm{Ca}^{++}\right] \times\left[\mathrm{HCit}^{=}\right]}{[\mathrm{CaHCit}]}=K_{\mathrm{CaHCit}}=10^{-2.3}
$$

From equations 55, 59, and 61 we have constructed a grid nomogram (fig. 3) with four variables, viz., Total $\mathrm{Ca}$, Total Citrate, $\mathrm{pH}$, and $\mathrm{Ca}^{++}$, which facilitates the calculation of $\mathrm{Ca}^{++}$concentrations at varying $\mathrm{pH}$, and has been made use of by Ransmeier and McLean (1938) for the calculation of $\mathrm{Ca}^{++}$concentrations in citrated plasma.

\footnotetext{
${ }^{9}$ The applications of the law of chemical equilibrium to the solubility of difficultly soluble salts are not here reviewed. The present status of the problem of the solubility relationships of the salts of bone, which is beset by a number of difficulties, is reviewed by Logan and Taylor (1937).
} 
The dissociation constant of magnesium citrate has been found (Hastings et al., 1934) to be approximately that of calcium citrate.

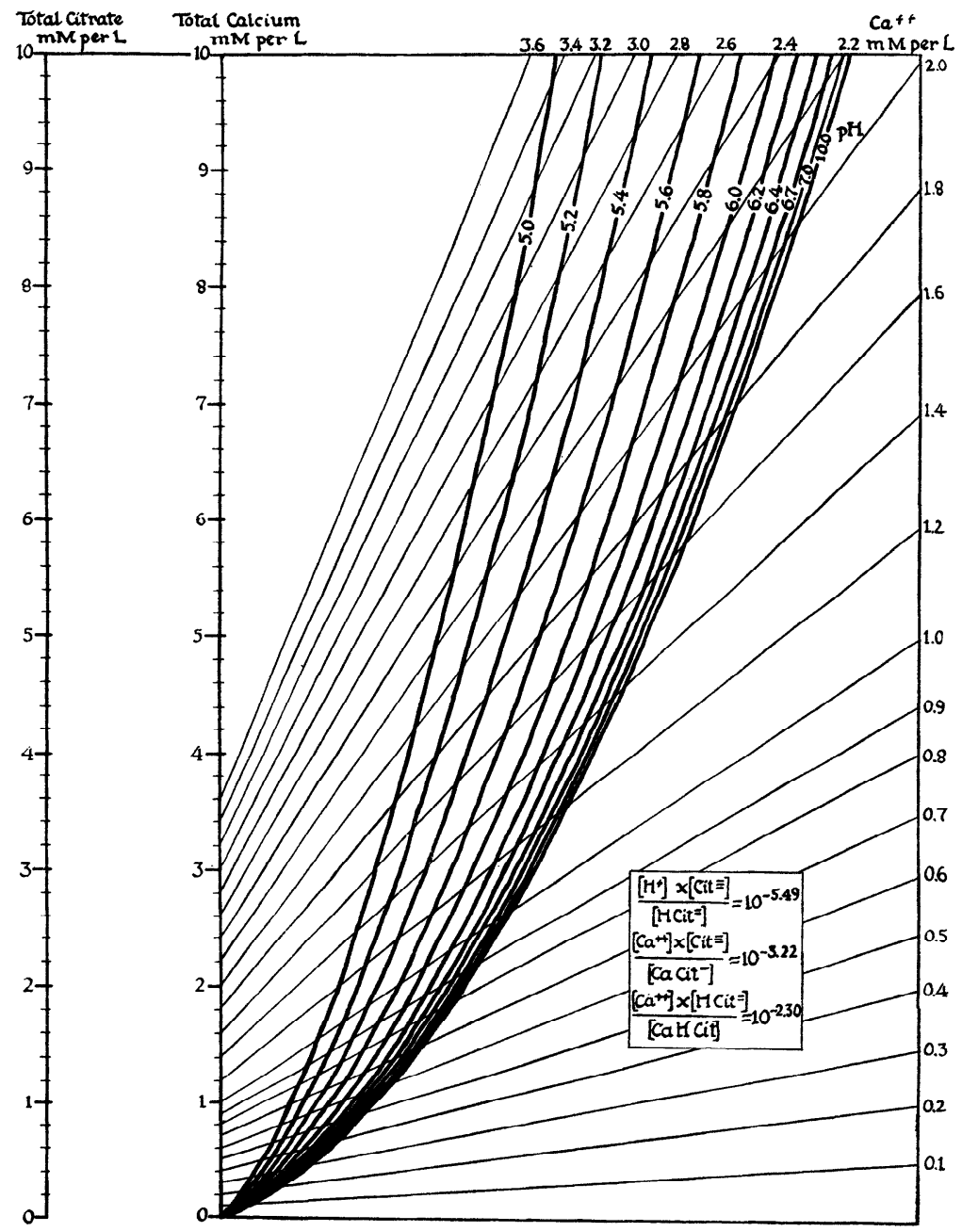

Fig. 3. Grid nomogram for calculation of $\mathrm{Ca}^{++}$concentrations from Total $\mathrm{Ca}$, Total Citrate, and $\mathrm{pH}$. If a straight line is drawn through given points on Total $\mathrm{Ca}$ and Total Citrate scales, the $\mathrm{Ca}^{++}$concentration can be read by interpolation between iso- $\mathrm{Ca}^{++}$lines at the point where the line drawn intersects the line representing the given $\mathrm{pH}$. I am indebted to Solomon J. Klapman for construction of this nomogram. 
When calcium and magnesium are both present in a citrate-containing solution each influences the ionization of the other. $\Lambda$ grid nomogram with four variables, viz., 'Total $\mathrm{Ca}$, Total $\mathrm{Mg}$, Total Citrate, and $\mathrm{Ca}^{++}$, similar to figure 3 , may be readily constructcd for use at $\mathrm{pH}$ above 7.0, in the range in which citric acid is practically completely dissociated.

The state of Calcium in protein-containing fluids. Using the frog-heart method for estimation of $\mathrm{Ca}^{++}$concentrations, McLean and Hastings (1935) were able to show that calcium proteinate dissociates as a weak electrolyte, and that the ionization of calcium in a protein-containing fluid, such as serum or plasma, may as a first approximation be described by the equation

$$
\mathrm{CaProt} \rightleftharpoons \mathrm{Ca}^{++}+\text {Prot }^{=}
$$

and the corresponding mass law equation

$$
\frac{\left[\mathrm{Ca}^{++}\right] \times\left[\mathrm{Prot}^{=}\right]}{[\mathrm{CaProt}]}=K_{\mathrm{CaProt}}
$$

the value found for $K_{\mathrm{CaProt}}$ in the case of the combined serum proteins being $10^{-2.22}$.

An uncertain factor in this equation is the expression of protein in terms of molal concentrations with respect to its calcium-combining groups. McLean and Hastings assumed that the figures obtained from titration curves of protein with base were applicable, at the same time pointing out the weakness in this assumption.

A second uncertain factor is the assumption that protein behaves toward calcium as if the former were a series of divalent ions. It now appears that this assumption is not necessary, and that the equations may equally well be written

$$
\begin{aligned}
& \mathrm{CaProt}^{+} \rightleftharpoons \mathrm{Ca}^{++}+\text {Prot }^{-} \\
& \frac{\left[\mathrm{Ca}^{++}\right] \times\left[\mathrm{Prot}^{-}\right]}{\left[\mathrm{CaProt}^{+}\right]}=K_{\mathrm{CaProt}^{+}},
\end{aligned}
$$

since the experimental data show merely that there is a one to one relationship between calcium and protein ions, and are not sufficiently accurate to distinguish between equations 63 and 65 .

Greenberg, Larson and Tufts (1934-35) by an ingenious handling of the mass law equation, have avoided both of these uncertainties. They write the equation,

$$
\frac{\text { Total Protein }}{[\text { CaProt }]}=\frac{1}{A}+\frac{B}{\left[\mathrm{Ca}^{++}\right]}
$$


in which Total Protein is expressed in grams per liter, and $\left[\mathrm{Ca}^{++}\right]$and [CaProt] in molal concentrations. $A$ then becomes the factor ncccssary to convert Total Protein to terms of molal concentrations, and $A \times B$ becomes the cquilibrium constant $K$. When observed data obey the mass law a straight line is obtained on plotting $\frac{\text { Total Protein }}{\text { [CaProt] }}$ against $\frac{1}{\left[\mathrm{Ca}^{++}\right]}$, the value $A$ is given by the reciprocal of the point of intersection of the straight line on the Total Protein/[CaProt] axis, and the value of $B$ is given by the slope of the line.

By this method Greenberg, Larson and Tufts found the calciumcombining power of protein at $\mathrm{Ca}^{++}=\infty$ to be much lower than that calculated from the titration curves with base and found a value of $10^{-2.75}$ for $K_{\mathrm{CaProt}}$ for serum proteins as compared with $10^{-2.22}$ as reported by McLean and Hastings, the difference in the numerical value for $K_{\mathrm{CaProt}}$ being in part attributable to the lower protein factor. Larson (1937) has extended these observations and now finds a somewhat higher protein factor and a value of $10^{-2.44}$ for $K_{\mathrm{CaProt}}$.

These discrepancies are no doubt due in part to the differences in method for estimation of $\mathrm{Ca}^{++}$. The method of Greenberg, Larson and Tufts for estimation of the protein factor, while sound in principle, depends upon extrapolation from the conditions at low $\mathrm{Ca}^{++}$concentrations to those at $\mathrm{Ca}^{++}=\infty$. For $\mathrm{Ca}^{++}$concentrations within the range found in the serum of man the differences calculated by using different protein factors are generally within the limits of observational error. Further refinement of the values for the protein factor and $K_{\mathrm{CaProt}}$ will depend upon methods for determining $\mathrm{Ca}^{++}$concentrations with greater accuracy and over a wider range.

The calculation most commonly made by the use of equation 63 is that of $\mathrm{Ca}^{++}$from total calcium and total protein. Starting with the equations

$$
\begin{gathered}
\text { Total } \mathrm{Ca}=\mathrm{Ca}^{++}+\mathrm{CaProt} \\
\text { Total Protein }=\mathrm{Prot}^{=}+\mathrm{CaProt}
\end{gathered}
$$

and the mass action equation 61 , there may be derived the equation

$$
[\text { Total } \mathrm{Ca}]=\frac{\left[\mathrm{Ca}^{++}\right] \times[\text {Total Prot }]}{\left[\mathrm{Ca}^{++}\right]+K}+\left[\mathrm{Ca}^{++}\right]
$$

from which the cartesian nomogram published by McLean and Hastings is readily constructed. McLean (1935) has published a simplified method for the construction of this and of similar nomograms. 
Previous writers had shown that the level of total calcium in the serum, in the absence of any disturbance in calcium metabolism, is directly correlated with the concentration of total protein, and had expressed this relationship in the form of the empirical regression equation

$$
\text { Total } \mathrm{Ca}=m \text { Total Protein }+b
$$

McLean and Hastings noted the similarity of this equation to equation 69 above, assuming the $\mathrm{Ca}^{++}$concentration in the fluids studied to be approximately constant. From the data in the literature they were able to calculate values for $K_{\mathrm{CaProt}}$ in fair agreement with those arrived at by the frog-heart method.

OXIDATION-REDUCTION EQUILIBRIA. The modern use of oxidationreduction potentials in the study of biological oxidations is an outgrowth of the pioneer work of Clark (1923), who applied the law of chemical equilibrium to oxidation-reduction systems, and showed how the electrode potential of such a system depends upon the equilibrium constant. For general treatment of the subject reference is made to the reviews by Clark $(1934,1938)$.

Oxidation and reduction are characterized by the transfer of electrons. The essential feature of oxidation is the loss of electrons, which may be accompanied by the addition of oxygen or the loss of hydrogen. Reduction is the reverse of oxidation. For our present purposes it is convenient to consider a case in which the reaction involves only the transfer of electrons.

$$
\mathrm{H}_{2}+2 \mathrm{Fe}^{+++} \rightleftharpoons 2 \mathrm{H}^{+}+2 \mathrm{Fe}^{++}
$$

At equilibrium we may write

$$
\frac{\left[\mathrm{H}^{+}\right]^{2}+\left[\mathrm{Fe}^{++}\right]^{2}}{\left[\mathrm{H}_{2}\right]+\left[\mathrm{Fe}^{+++}\right]^{2}}=K^{10}
$$

Since this reaction involves only the transfer of electrons we may let it occur in two half-cells, with provision for the passage of electrons.

$$
\begin{gathered}
\mathrm{H}_{2} \rightleftharpoons 2 \mathrm{H}^{+}+2 \mathrm{e} \\
\mathrm{e}+\mathrm{Fe}^{+++} \rightleftharpoons \mathrm{Fe}^{++}
\end{gathered}
$$

If we now fix the first half-cell at the standard condition of 1 atmos-

${ }^{10}$ To be theoretically exact this subject should be developed in terms of activities. For the sake of simplicity, activity coefficients are here neglected. 
phere of $\mathrm{H}_{2}$ and $\mathrm{N} / 1 \mathrm{H}^{+}$the ratio $\left[\mathrm{H}^{+}\right]^{2} /\left[\mathrm{H}_{2}\right]$ becomes unity, and when the second half-cell is in equilibrium with the first, equation 72 becomes

$$
\frac{\left[\mathrm{Fe}^{++}\right]}{\left[\mathrm{Fe}^{+++}\right]}=\sqrt{K}
$$

It is seen that under these standard conditions, and at equilibrium, the proportion of $\mathrm{Fe}^{++}$to $\mathrm{Fe}^{+++}$is fixed by the equilibrium constant. If on the other hand we fix the ratio $\mathrm{Fe}^{++} / \mathrm{Fe}^{+++}$at unity and permit equilibrium to be attained by a change in the other half-cell the ratio $\left[\mathrm{H}^{+}\right]^{2} /\left[\mathrm{H}_{2}\right]$ is determined by the equilibrium constant. In both cases the tendency of reactions 73 and 74 to proceed to the right or the left, or in other words the tendency of any system to give up or accept electrons, is described by the value of $K$. Thus if we allow $K$ in equation 75 , and hence in equation 72 , to decrease, reaction 74 proceeds to the left, with loss of electrons or oxidation of $\mathrm{Fe}^{++}$to $\mathrm{Fe}^{+++}$. If two oxidation-reduction systems are mixed, and if a reaction occurs, the system with the lower value for $K$ will lose electrons, or become oxidized, while the system with the higher value for $K$ will accept these electrons and become reduced. The prediction of the possibility and of the direction of any oxidation-reduction reaction thus requires nothing more than a knowledge of the value of the equilibrium constant for each of the systems. This was clearly pointed out by Clark (1923) and the subject has recently been reviewed in detail from this standpoint by Hogness and Johnson (1937), without reference to thermodynamics.

Since the characteristic method of study of oxidation-reduction systems is by measurement of the electrical potentials of such systems, and since the chief concern in the investigation of biological oxidations is with changes in free energy, thermodynamic treatment of this subject is at once more useful and more descriptive.

Substituting $-\Delta F=\mathrm{nEF}$, in which $\mathrm{n}$ is the number of equivalents reacting, $E$ the electromotive force, and $F$ the faraday, in equation 22 above, and writing in terms of concentrations we have

$$
\mathrm{E}=\frac{R T \ln K}{\mathrm{nF}}+\frac{R T}{\mathrm{nF}} \ln \frac{[\mathrm{A}]^{\mathrm{a}} \times[\mathrm{B}]^{\mathrm{b}}}{[\mathrm{C}]^{\mathrm{c}} \times[\mathrm{D}]^{\mathrm{d}}}
$$

or for the specific case of the reaction shown in equations 71 and 72

$$
\mathrm{E}=\frac{R T \ln K}{2 \mathrm{~F}}+\frac{R T}{2 \mathrm{~F}} \ln \frac{\left[\mathrm{H}_{2}\right] \times\left[\mathrm{Fe}^{+++}\right]^{2}}{\left[\mathrm{H}^{+}\right]^{2} \times\left[\mathrm{Fe}^{++}\right]^{2}}
$$


from which

$$
\mathrm{E}=\frac{R T \ln K}{2 \mathrm{~F}}+\frac{R T}{\mathrm{~F}} \ln \frac{\left[\mathrm{H}_{2}\right]^{\frac{1}{2}} \times\left[\mathrm{Fe}^{+++}\right]}{\left[\mathrm{H}^{+}\right] \times\left[\mathrm{Fe}^{++}\right]}
$$

By reference to the standard hydrogen electrode $\left(\mathrm{N} / 1 \mathrm{H}^{+}\right.$and one atmosphere $\left.\mathrm{H}_{2}\right)\left[\mathrm{H}_{2}\right]^{1 / 2} /\left[\mathrm{H}^{+}\right]$becomes unity, and if $\mathrm{Fe}^{+++} / \mathrm{Fe}^{++}$is unity we have, since $\ln 1=0$

$$
\mathrm{E}_{\mathrm{h}}=\mathrm{E}_{0}=\frac{R T \ln K}{\mathrm{nF}}
$$

in which $\mathrm{E}_{\mathbf{h}}$ is the electrode potential referred to the standard hydrogen electrode and $\mathrm{E}_{\mathrm{o}}$ is the potential under the same standard conditions of reference, and at half oxidation of the oxidation-reduction system. $\mathrm{E}_{\mathrm{o}}$ thus characterizes the system, and since $E_{o}$ is a logarithmic function of the equilibrium constant the system may equally well be characterized by $K$, as shown above.

For conditions other than half oxidation, but at the standard conditions for reference, equations 78 and 79 become

$$
\mathrm{E}_{\mathrm{h}}=\mathrm{E}_{0}+\frac{R T}{\mathrm{~F}} \ln \frac{\left[\mathrm{Fe}^{+++}\right]}{\left[\mathrm{Fe}^{++}\right]}
$$

or more generally, for any system involving $\mathrm{n}$ equivalents

$$
\mathrm{E}_{\mathrm{h}}=\mathrm{E}_{0}+\frac{R T}{\mathrm{nF}} \ln \frac{\text { [Oxidant }]}{\text { [Reductant }]}
$$

which is the standard equation for oxidation-reduction potentials.

The Change IN Free energy. From the above, and from equation 23 it may be seen that the free energy change, $\Delta F$, of a reaction, the equilibrium constant, and the electromotive force of a system, all under standard conditions, are related as follows:

$$
-\Delta F=R T \ln K=\mathrm{nEF}
$$

and it has been pointed out in the introduction that the data obtained by a variety of methods may be expressed in the terms most appropriate to the subject under consideration.

The free energy change of a reaction may be determined by purely thermal methods, but until recently applications of such methods to reactions of biological interest have been few. Borsook (1935) has undertaken the systematic collection of thermochemical data and has extensively reviewed the possibilities of their application. Brief refer- 
ence will be made here to a specific case illustrating the relationships expressed in equation 82.

In the presence of an appropriate enzyme succinic acid is oxidized to fumaric acid. The system is of itself not electromotively active, but if a small amount of a dye, such as methylene blue, is added the potential of the system is transferred by the dye to the elcctrode. Moreover, if the constants for the dye system are known the potential of the system with which it is in equilibrium, and consequently its equilibrium constant, may be derived from colorimeter readings. For the succinatefumarate system the equilibrium constant was determined colorimetrically by Quastel and Whetham (1924), colorimetrically and electrometrically by Thunberg (1925), electrometrically by Lehmann (1930), and by Borsook and Schott (1931).

Borsook and Schott also calculated the free energy change for the same reaction from thermal data, the details of their calculations being given also by Borsook (1935). They compared the values for $\Delta F$ arrived at by this method with those derived from the data obtained by other methods, and found a remarkable agreement. On account of certain advantages of the thermal method, as stated by Borsook, it seems probable that the thermal method for studying free energy changes may come into more general use.

A thermodynamic principle, as yet applied to but few reactions of biological interest, is that the free energy change is a quantity determined by the initial and final states of the system. For a catenary reaction, of which there are many examples in metabolic processes, the change in free energy may be calculated from the initial and final states, without reference to the intermediate reactions. Thus Burk (1929) has calculated the free energy of the breakdown of glycogen to lactic acid in muscle from thermal data. Moreover, if the data for the intermediate reactions are available the change in free energy from the initial to the final states may be calculated by combining these data. Some examples are given by Wilson and Peterson (1931).

Earlier applications of thermochemistry to reactions of biological interest were chiefly concerned with the heat of reaction, a quantity which is of itself of less significance than the change in free energy. The heat of reaction of hemoglobin with oxygen was studied by Brown and Hill (1923) and their paper illustrates the applicability of such data to the study of chemical equilibrium.

Enzymatic REACTIONs. The study of enzymes, and of the reactions of biological interest catalyzed by them, has been in large part de- 
pendent upon the application of the law of chemical equilibrium to oxidation-reduction potentials and more recently upon the use of thermal data for calculation of free energy changes. Study of the kinetics of enzymatic reactions has also been greatly aided by derivations from the law of mass action. No attempt is made here to review the voluminous literature of this special field. For consideration of these important applications of the law of mass action the forthcoming review by Barron may be consulted.

\section{CONCLUSION}

So far as the author is aware this is the first attempt to review the contributions of the law of chemical equilibrium to the study of biological problems. It might be thought a priori that this law, being a statement of the conditions in a chemical system at equilibrium, might be of very limited application to biological processes. To the contrary, its rôle in the elucidation of the mechanisms concerned with the acid-base balance and in the discovery of physiologically important properties of hemoglobin can hardly be overestimated, and it has opened the way for equally significant progress in the understanding of the complexities of intermediary metabolism. It should be increasingly useful as biology becomes more and more concerned with the analysis of chemical processes in the living organism.

\section{REFERENCES}

AdaIR, G. S. J. Biol. Chem. 63: 529, 1925.

Allcock, H. J. AND J. R. Jones. The nomogram. London, Sir Isaac Pitman and Sons, 1932.

Arrhenius, S. Ztschr. f. Physikal. Chemie 1: 631, 1887.

BARCROFT, J. The respiratory function of the blood. Cambridge University Press, 1914.

Barron, E. S. G. Physiol. Reviews (in preparation).

Berthollet, C. L. Recherches sur les lois de l'affinité. Paris, 1801. Translation in Ostwald's Klassiker der exacten Wissenschaften, no. 74, Leipsig, 1896.

Borsoor, H. Ergebn. d. Enzymforschung 4: 1, 1935.

Borsook. H. AND H. F. SсHотt. J. Biol. Chem. 92: 535, 1931.

Brown, W. E. L. ANd A. V. Hrll. Proc. Roy. Soc. London. B. 94: 297, 1923.

Burk, D. Proc. Roy. Soc. London. B. 104: 153, 1929.

ClaRK, W. M. Public Health Reports 38: 443, 1923.

Medicine 13: 207, 1934.

J. Applied Physics 9: 97, 1938.

EdGAR, G. Treatise on physical chemistry. Edited by H. S. Taylor, Vol. I, pp. 415-466. New York, D. van Nostrand Co., 1931. 
Faurholt, C. J. de Chimie Physique 21: 400, 1924.

Ferry, R. M. And A. A. Green. J. Biol. Chem. 81: 175, 1929.

Gremenbrg, D. M., C. E. Larson and E. V. Tufts. Proc. Soc. Exper. Biol. and Med. 32: 647, 1934-35.

Guldberg, C. M. and P. WaAge. Études sur les Affinités Chimiques. Christiania. 1867. Translation in Ostwald's Klassiker der exacten Wissenschaften, no. 104, Leipsig, 1899.

Hasselbalch, K. A. Biochem. Ztschr. 78: 112, 1916-17.

Hastings, A. B., F. C. McLean, L. Eichelberger, J. L. Hall and E. DaCosta. J. Biol. Chem. 107: 351, 1934.

Hastings, A. B. And J. Sendroy, Jr. J. Biol. Chem. 65: 445, 1925.

Hastings, A. B. and A. H. Steinhaus. Am. J. Physiol. 96: 538, 1931.

Henderson, L. J. Am. J. Physiol. 21: 427, 1908.

J. Biol. Chem. 41: 401, 1920.

Blood: A study in general physiology. New Haven, Yale University Press, 1928.

Henriques, O. M. Biochem. Ztschr. 200: 1, 1928.

Hill, A. V. J. Physiol. 40: Proc. Physiol. Soc. p. iv, 1910.

Hogness, T. R. AND W. C. Johnson. Qualitative analysis and chemical equilibrium. New York, Henry Holt and Co. 1937.

HÜFNer, G. Arch. f. Physiol. 1890, p. 1.

LARSON, C. E. Dissertation in University of California Libraries, 1937.

Lehmann, J. Skand. Arch. Physiol. 58: 173, 1930.

Lewis, G. N. ANd M. Randall. Thermodynamics. New York. McGraw-Hill Book Co., 1923.

Logan, M. A. AND H. L. TAYlor. J. Biol. Chem. 119: 293, 1937.

Margaria, R. and A. A. Green. J. Biol. Chem. 102: 611, 1933.

McLean, F. C. Science 82: 104, 1935.

McLean, F. C. and A. B. Hastings. J. Biol. Chem. 108: 285, 1935.

MUIR, M. M. P. A history of chemical theories and laws. New York, John Wiley and Sons, 1909.

Muds, J. And H. Imber. Mathematisk-fysiske Meddelelser 13: no. 19, 1936.

Peters, J. P. and D. D. Van Slyke. Quantitative clinical chemistry. Vol. I. Interpretations. Baltimore, Williams \& Wilkins Co., 1931.

Quastel, J. H. and M. D. Whetham. Biochem. J. 18: 519, 1924.

Ransmeier, J. C. and F. C. McLean. Am. J. Physiol. 121: 488, 1938.

Roughton, F. J. W. Physiol. Revicws 15: 241, 1935.

SabBatani, L. Arch. ital. biol. 36: 397, 1901.

Sendroy, J., JR. Ann. Reviews of Biochem. 7: 231, 1938.

Sendroy, J., Jr., S. Seelig and D. D. Van Slyke. J. Biol. Chem. 106: 463, 1934.

Shock, N. W. and A. B. Hastings. J. Biol. Chem. 112: 239, 1935-36.

Sidwell, A. E., Jr., R. H. MUnch, E. S. G. Barron and T. R. Hogness. J. Biol. Chem. 123: 335, 1938.

Stadie, W. C. and E. R. Hawes. J. Biol. Chem. 77: 265, 1928.

Stadie, W. C. and H. O'Brien. J. Biol. Chem. 112: 723, 1935-36. J. Biol. Chem. 117: 439, 1937.

Stieglitz, J. Qualitative chemical analysis. New York, The Century Co., 1911. 
TAYLOR, H. S. Treatise on physical chemistry. Vol. I. New York, D. Van Nostrand and Co., 1931.

Thiel, A. and R. Strohecker. Berichte deutsch. chem. Gesellsch. 47: 945, 1061, 1914.

Thunberg, T. Skand. Arch. Physiol. 46: 339, 1925.

VAN Slyke, D. D. Physiol. Reviews 1: 141, 1921.

J. Biol. Chem. 52: 525, 1922.

Van Slyke, D. D., A. B. Hastings, C. D. Murray and J. Sendroy, Jr. J. Biol. Chem. 65: 701, 1925.

VAN Slyke, D. D. AND J. Sendroy, JR. J. Biol. Chem. 79: 781, 1928.

VAN'т Hoff, J. H. Bericht. deutsch. chem. Gesellsch. 10: 669, 1877.

Walker, J. AND W. Cormack. J. Chem. Soc. (London) 77: 5, 1900.

Wenzel, C. F. 1777 (cited by MUIR, 1909, from edition of 1800).

Wilson, P. W. and W. H. Peterson. Chem. Reviews. 8: 427, 1931. 